\title{
EVALUASI TINGKAT PELAYANAN JALAN DAN PENGARUHNYA TERHADAP ANGKA HENTI STOP
}

\author{
Ridayati \\ Program studi Teknik Sipil STTNAS \\ e-mail: ridayati@gmail.com
}

\begin{abstract}
The number of students who coming from the outside of Yogyakarta is the main cause of the rapid growth. Hence, it's impacted to transportation sector. In addition, one of the densenly traffic areas in Yogya phone's Intersection. The purposes of this paper are to analize and evaluate the level of service provided by jogja phone's intersection, and also identify the effect of saturation degree to number of stop. Based on traffic analysis cycle time, the service level to the traffic flow at the Jogja phone's intersection at the present time is very low, that is $F$ category. After the rearrangement process using MKJI 1997, it obtained a B level of service. In addition, the results of the analysis using SPSS 15, there is no significant effect between the degrees of saturation to the numbers of stop.
\end{abstract}

Keywords: Degree of Saturation, Number of Stop, dan Regression

\section{ABSTRAK}

Banyaknya para pelajar yang datang dari luar daerah untuk menimba ilmu menjadi penyebab utama pesatnya Pertumbuhan kota Yogyakarta. Hal ini tentu berimplikasi juga pada sektor transportasi. Salah satu kawasan yang mempunyai volume arus lalulintas cukup padat adalah simpang tiga bersinyal jogja phone Yogyakarta. Tulisan ini bertujuan untuk menganalisis dan mengevaluasi tingkat pelayanan yang diberikan oleh simpang tiga bersinyal Jogja Phone serta mengetahui pengaruh derajat kejenuhan terhadap angka henti stop. Berdasarkan analisis waktu siklus lalulintas, tingkat pelayanan terhadap arus lalulintas pada simpang tiga Jogja Phone Yogyakarta pada masa sekarang masuk dalam kategori F yaitu sangat rendah. Setelah dilakukan pengaturan kembali menggunakan metode MKJI 1997 diperoleh tingkat pelayanan B. Hasil analisis menggunakan SPSS 15 berupa regresi linear juga diketahui bahwa tidak ada pengaruh secara signifikan antara derajat kejenuhan terhadap angka henti stop.

Kata kunci: Derajat Kejenuhan, Angka Henti Stop, Regresi

\section{PENDAHULUAN}

Persimpangan jalan mempunyai peranan yang sangat penting guna menjamin kelancaran arus lalu lintas. Pada kenyataannya di daerah persimpangan jalan sering terjadi kemacetan lalu lintas. Keberadaaan persimpangan harus dikelola dengan baik sehingga didapatkan suatu simpang yang baik juga. Hal yang dapat dilakukan untuk memperoleh kelancaran lalu lintas tersebut adalah dengan menghilangkan konflik pada persimpangan. Cara yang dapat digunakan adalah dengan mengatur kembali lalu lintas yang terjadi pada persimpangan.

Yogyakarta merupakan salah satu contoh yang mempunyai banyak konflik pada persimpangan jalan. Pada sepuluh tahun terakhir ini Yogyakarta sudah mulai kurang nyaman dengan adanya kemacetan lalu lintas pada persimpangan jalan. Pada sejumlah titik jalan yang bukan tergolong jalan utama menjadi sulit untuk menyeberang. Jika sebelumnya para pakar dan pengamat memperkirakan sekitar lima belas tahun kemudian akan menyamai kemacetan lalu lintas di ibukota, maka dengan melihat tingkat kemacetan saat ini mungkin hanya membutuhkan waktu kurang dari lima tahun akan menyamai kemacetan lalu lintas di Jakarta. Hal ini disebabkan oleh tingginya perkembangan dan pertumbuhan kota Yogyakarta. Banyaknya para pelajar yang datang dari luar daerah ke kota Yogyakarta untuk menimba ilmu menjadi penyebab utama pesatnya Pertumbuhan kota Yogyakarta. 
Jumlah kendaraan yang melewati jalan-jalan dikota Yogyakarta terutama kendaraan bermotor meningkat cepat sehingga kemampuan dan daya dukung jalan untuk menampung mobilitas penduduk, barang dan jasa sangat penting.

Salah satu kawasan yang mempunyai volume arus lalulintas cukup padat adalah simpang tiga bersinyal Jogja Phone (Jalan Jenderal Sudirman dengan Jalan C. Simanjuntak). Jalan tersebut berdekatan dengan sekolah, terminal, restaurant, pasar, hotel, mall ,pom bensin. Hal ini menyebabkan terjadinya kemacetan dan antrian sehingga perlu dianalisis dan dicari solusi pemecahannya.

Penelitian ini menganalisis dan mengevaluasi tingkat pelayanan yang diberikan oleh simpang tiga bersinyal Jogja Phone Yogyakarta setelah adanya alternatif desain, waktu all red, waktu hijau baru dan geometrik simpang, serta mengetahui pengaruh derajat kejenuhan terhadap angka henti stop. Hasilnya diharapkan dapat mencerminkan optimalitas, efektivitas dan efisiensi kondisi transportasi perkotaan Yogyakarta secara umum.

Hal penting yang menjadi dasar analisis adalah simpang bersinyal, tingkat pelayanan jalan dan regresi linear. Lampu lalulintas (traffic light) adalah semua peralatan pengatur lalulintas yang menggunakan tenaga listrik kecuali lampu kedip, rambu, dan marka jalan untuk mengarahkan atau memperingatkan pengemudi kendaraan bermotor, pengendara sepeda atau pejalan kaki [1]. Ukuran dasar yang digunakan dalam mendefinisikan arus lalulintas adalah kosentrasi dan kecepatan. Aliran dan volume sering dianggap sama, meskipun istilah aliran lebih tepat menyatakan arus lalulintas dan mengandung pengertian jumlah kendaraan yang melewati suatu titik dalam ruang selama interval waktu tertentu [2].

Simpang-simpang bersinyal merupakan bagian dari sistem kendali waktu tetap yang dirangkai atau sinyal aktual kendaraan terisolir. Simpang bersinyal biasanya memerlukan metode dan perangkat lunak khusus dalam analisanya. Kapasitas simpang dapat ditingkatkan dengan menerapkan aturan prioritas sehingga simpang dapat digunakan secara bergantian. Pengendalian lampu lalu lintas dapat digunakan alat pemberi isyarat lalu lintas (traffic signal) atau sinyal lalu lintas. Pada umumnya penggunaan sinyal lalu lintas pada persimpangan dipergunakan untuk satu atau lebih alasan berikut ini [3]: (1) untuk menghindari kemacetan simpang akibat adanya konflik arus lalu lintas, sehingga terjamin bahwa suatu kapasitas tertentu dapat dipertahankan, bahkan selama kondisi lalu lintas jam puncak, (2) untuk memberi kesempatan kepada kendaraan dan/atau pejalan kaki dari jalan simpang (kecil) untuk memotong jalan utama, (3) untuk mengurangi jumlah kecelakaan lalu lintas akibat tabrakan antara kendaraan-kendaraan dari arah yang bertentangan.

Tingkat pelayanan pada persimpangan jalan dengan lampu lalulintas didefinisikan sehubungan dengan tundaan (delay). Tundaan ini mengakibatkan kegelisahan bagi pengemudi yaitu meningkatnya frustasi pengemudi, kebutuhan bahan bakar kendaraan dan hilangnya waktu perjalanan. Kriteria tingkat pelayanan ditetapkan dalam bentuk waktu berhenti rerata (average stopped delay) tiap kendaraan dalam periode analisis selama 15 menit [4].

Hubungan antara tingkat pelayanan dan tundaan dapat digolongkan dalam beberapa tingkat pelayanan. Tingkat pelayanan A menggambarkan operasi tundaan sangat rendah yaitu kurang dari 0,5 detik tiap kendaraan. Tingkat pelayanan B menggambarkan pengoperasian dengan tundaan yang sangat rendah dalam interval 5,1-15 detik tiap kendaraan. Tingkat pelayanan $\mathrm{C}$ menggambarkan pengoperasian yang lebih tinggi dalam interval 15,1-25 detik tiap kendaraan. Tingkat pelayanan D menggambarkan pengoperasian dengan kisaran waktu 25,1-40 detik tiap kendaraan. Tingkat pelayanan E menggambarkan pengoperasian dengan tundaan kisaran waktu 40,1-60 detik tiap kendaraan dan dianggap 
sebagai batas penundaan yang dapat diterima. Tingkat Pelayanan $\mathrm{F}$ menggambarkan tingkat pengoperasian dengan tundaan lebih dari 60 detik tiap kendaraan. Ini dianggap sebagai penundaan yang tidak dapat diterima oleh pengemudi [3].

Waktu hijau efektif adalah waktu yang dapat digunakan untuk melewatkan kendaraan dalam fase, terdiri atas waktu hijau dan sebagian waktu kuning [3]. Permulaan arus berangkat menyebabkan terjadinya "kehilangan awal" dari waktu hijau efektif, arus berangkat setelah akhir waktu hijau menyebabkan suatu "tambahan akhir" dari waktu hijau efektif.

Waktu hijau efektif = tampilan waktu hijau - kehilangan awal + tambahan akhir.

Menentukan waktu hilang (LTI) sebagai jumlah dari waktu antar hijau per siklus

$L T I=\sum(M E R A H S E M U A+K U N I N G) i=\sum I G i$

MERAH SEMUA $=\frac{\left(L_{E V}+I_{E V}\right)}{V_{E V}}-\frac{L_{A V}}{V_{A V}}$

Keterangan :

$L_{E V}, L_{A V}=$ jarak dari garis henti ke titik konflik masing-masing untuk kendaraan yang berangkat dan yang datang (m)

$I_{E V} \quad=$ panjang kendaraan yang berangkat $(\mathrm{m})$

$V_{E V}, V_{A V}=$ kecepatan masing-masing untuk kendaraan yang berangkat dan yang datang $(\mathrm{m} / \mathrm{dtk})$

Waktu siklus sebelum penyesuaian:

$c_{u a}=(1,5 \times L T I+5) /(1-I F R)$

Keterangan :

$c_{u a}=$ Waktu siklus sebelum penyesuaian sinyal (det)

$L T I=$ Waktu hilang total per siklus (det)

$I F R=$ Rasio arus simpang waktu hijau $\left(g_{i}\right)$ :

$g_{i}=\left(c_{u a}-L T I\right) \times P R_{i}$

Keterangan :

$g_{i}=$ Tampilan waktu hijau pada fase $i$ (det)

$c_{u a}=$ Waktu siklus sebelum penyesuaian (det)

$L T I=$ Waktu hilang total per siklus (det)

$P R_{i}=$ Rasio fase

Waktu siklus yang disesuaikan (c)

$c=\sum g+L T I$

Keterangan :

$\sum g=$ Jumlah total waktu hijau (det)

LTI = Waktu hilang total per siklus (det)

Kapasitas $(C)$ dari masing-masing pendekat.

$C=S \times g / c$

Derajat kejenuhan $D S$ untuk masing-masing pendekat

$D S=Q / C$

Keterangan :

$Q=$ Arus lalulintas (smp/jam) 
Kendaraan terhenti :

(1) Menghitung angka henti (NS) untuk masing-masing pendekat yang didefinisikan sebagai jumlah rata - rata berhenti per smp (termasuk berhenti berulang dalam antrian) $N S=0,9 x\{N Q /(Q x c)\} \times 3600$

$N Q=$ Jumlah total kendaraan antri

(2) Menghitung jumlah kendaraan terhenti $\left(N_{S V}\right)$ (smp/jam) untuk masing-masing pendekat $N_{S V}=Q \times N S$

(3) Menghitung angka henti untuk seluruh simpang $\left(N S_{T O T}\right)$ dengan cara membagi jumlah kendaraan terhenti pada seluruh pendekat dengan arus simpang total $Q$ dalam kend/jam $N S_{T O T}=\sum N_{S V} / Q_{T O T}$

$Q_{T O T}=$ arus simpang total

Analisis regresi linear berganda digunakan untuk menemukan atau mengetahui persamaan regresi yang menunjukan pengaruh antara variabel terikat (angka henti stop) dengan variabel bebas yaitu derajat kejenuhan [8]. Rumus analisis regresi linear berganda adalah sebagai berikut:

$\mathrm{Y}=\mathrm{a}+\mathrm{bX}$

Keterangan :

$\mathrm{Y}=$ Angka henti stop

a $=$ Konstanta

$\mathrm{b}=$ Koefisien regresi dari variabel

$\mathrm{X}=$ derajat kejenuhan

Uji yang digunakan adalah uji t. Uji ini digunakan untuk melihat pengaruh variabel bebas secara individu terhadap variabel terikat [9]. Pengujian melalui uji $t$ adalah membandingkan $\mathrm{t}_{\text {hitung }}\left(\mathrm{t}_{h}\right)$ dengan $\mathrm{t}_{\text {tabel }}\left(\mathrm{t}_{t}\right)$ pada derajat signifikan 95\% $(\alpha=0,05)$.

Rumus Uji t:

$\mathrm{t}=\frac{b-\beta}{s_{b}}$

Keterangan :

$b=$ koefisien estimasi variabel

$\beta=$ koefisien beta awal

$s_{b}=$ standar deviasi

dengan tingkat keyakinan sebesar 95\%, atau $\alpha=0,05$

\section{METODOLOGI PENELITIAN}

Penelitian terhadap simpang tiga Jogja Phone Yogyakarta mengupas masalah lalulintas dengan menganalisis waktu sinyal. Dengan mengumpulkan data-data yang dibutuhkan berupa data primer dan sekunder, serta mengolah data-data tersebut menggunakan metode MKJI 1997. Dengan memprediksi tingkat pelayanan masa sekarang yang diberikan ruas jalan simpang tiga Jogja Phone Yogyakarta. Dengan metode MKJI 1997 penulis dapat juga merencanakan waktu sinyal yang baru yaitu waktu sinyal yang sudah ditambahkan dengan waktu khusus bagi penyeberang untuk setiap lengan pada simpang Jogja Phone Yogyakarta agar pejalan kaki mempunyai waktu untuk menyeberang serta mengetahui tingkat pelayanan baru yang didapatkan setelah adanya penambahan waktu khusus bagi penyeberang jalan. 
Selanjutnya dari data yang diperoleh diolah menggunakan SPSS 15 berupa regresi linear menggunakan uji $t$ untuk mengetahui pengaruh derajat kejenuhan terhadap angka henti stop di simpang tiga bersinyal Jogja Phone Yogyakarta.

\section{HASIL DAN PEMBAHASAN}

Besarnya derajat kejenuhan pada hari Senin pukul 12.30-13.30 Wib pada simpang tiga Jogja Phone Yogyakarta sudah melampaui angka 0,75 yaitu 1,33. Angka ini tergolong sangat tinggi. Hal ini berarti kapasitas pendekat sudah tidak dapat melayani pengguna jalan dengan baik, seperti yang terjadi pada pendekat barat dan utara. Selain itu pada masingmasing pendekat simpang tersebut menurut MKJI 1997 terjadi panjang antrian dan tundaan yang besar.

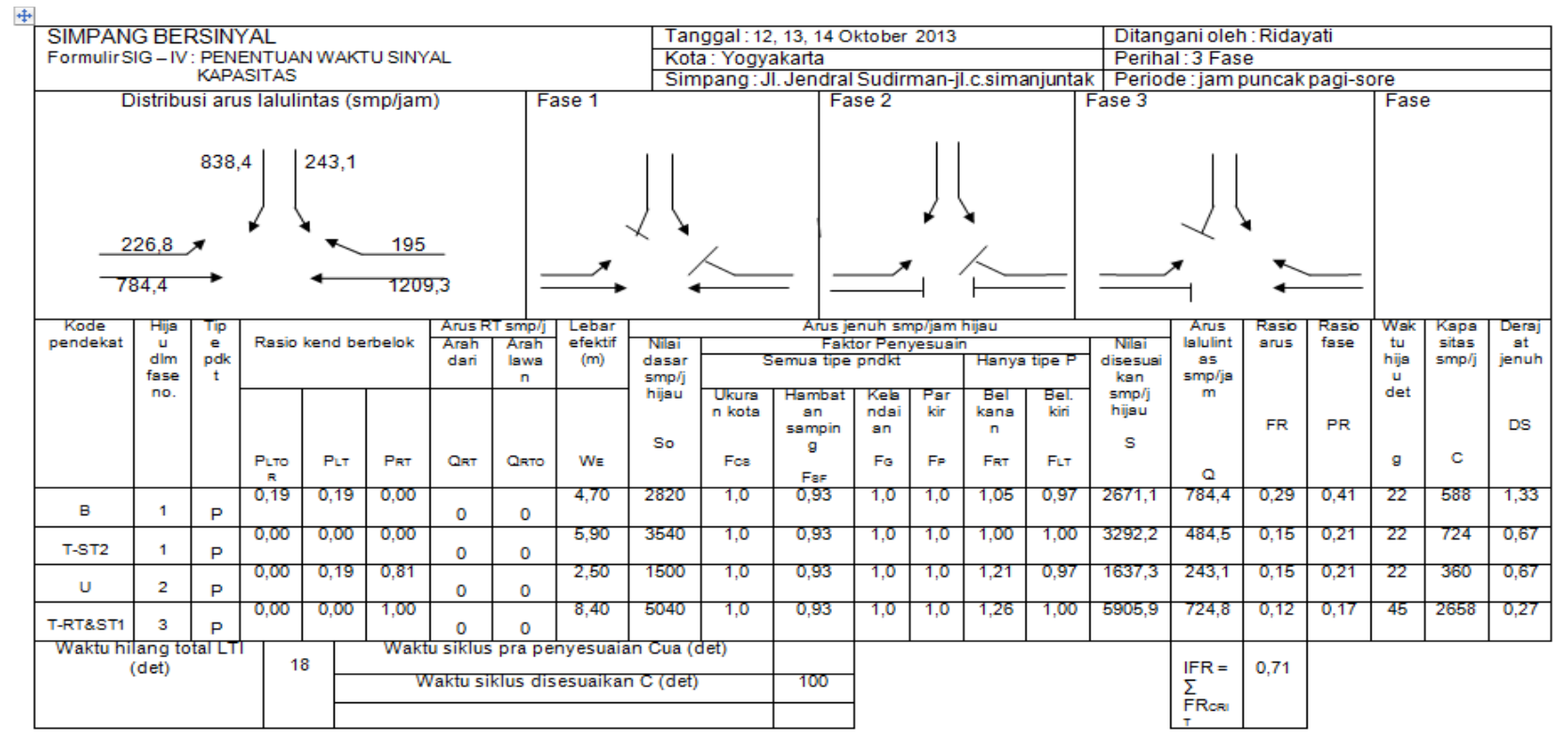

Gambar 1. Penentuan Waktu Sinyal

Masalah tersebut dapat diatasi dengan beberapa penyelesaian alternatif desain. Terdapat tiga alternatif desain yang akan dibahas guna mengatasi permasalahan yang terjadi yaitu dengan alternatif desain waktu hijau, alternatif desain geometrik jalan, dan alternatif desain waktu hijau disertai desain geometrik. Tiga alternatif tersebut akan dicoba dan dipilih salah satu hasil yang baik, dari hasil yang diperoleh diharapkan sesuai dengan persyaratan di dalam aturan MKJI 1997.

Pemecahan masalah lalulintas pada simpang tiga Jogja Phone Yogyakarta berdasarkan tingkat pelayanannya dijelaskan seperti berikut:

\section{Alternatif desain waktu hijau}

Dalam mengatasi besarnya panjang antrian yang cukup besar khususnya pada pendekat simpang arah barat dan utara cukup besar yaitu 643,53 meter dan 108 meter, sehingga perlu dilakukan alternatif desain pada waktu hijau $(g)$ di setiap lengan pendekat simpang. Pengaturan waktu siklus lampu lalulintas yang tepat dan disesuaikan dengan banyaknya arus lalulintas tiap pendekat akan dapat melayani lalulintas yang ada dengan efisien, sedangkan pengaturan waktu yang tidak tepat akan menyebabkan tidak seimbangnya prosentase yang lolos selama waktu hijau. Pengaturan yang baru ini diharapkan dapat menempatkan kebutuhan waktu siklus sesuai dengan proporsi arus 
lalulintas masing-masing pendekat. Perhitungan desain waktu hijau menggunakan rumus dari MKJI 1997 dengan langkah-langkah sebagi berikut:

(a). Waktu hilang total (LTI) Langkah pertama menghitung waktu hilang total (LTI) terlebih dahulu waktu merah semua fase, dihitung dengan persamaan berikut :

(1). Merah semua untuk fase $1 \rightarrow 2$

$$
=\frac{37,10+5}{10}-\frac{26,40}{10}=1,57 \approx 3 \mathrm{det}
$$

(2). Merah semua untuk fase $2 \rightarrow 3$

$$
=\frac{43,30+5}{10}-\frac{21,05}{10}=2,725 \approx 3 \mathrm{det}
$$

(3). Merah semua untuk fase $3 \rightarrow 1$

$$
\begin{aligned}
& =\frac{37,40+5}{10}-\frac{16,05}{10}=2,635 \approx 3 \text { det } \\
& \text { Waktu kuning total }(3 \text { det } / \text { fase }) \\
& =3 \times 3=9 \text { det } \\
& \text { Waktu hilang total }(L T I) \\
& L T I=(3+3+3)+9=18 \text { detik }
\end{aligned}
$$

(b). Waktu siklus sebelum penyesuaian $\left(c_{u a}\right)$ :

$$
\begin{aligned}
& c_{u a}=(1,5 \times L T I+5) /(1-I F R) \\
& \mathrm{c}_{\text {ua }}=(1,5 \times 17+5) /(1-0,71)=105,2 \text { detik }
\end{aligned}
$$

Waktu siklus $(c)$ dipilih antara $0,75 \times c_{0}$ sampai dengan $1,5 \times c_{\mathrm{o}}$ adalah

$$
\begin{aligned}
0,75 \times c_{\mathrm{o}} & =0,75 \times 105,2 \text { detik } \\
& =78,9 \text { detik } \approx 79 \text { detik. } \\
1,5 \times c_{\mathrm{o}} & =1,5 \times 105,2 \text { detik } \\
& =157,8 \text { detik } \approx 158 \text { detik. }
\end{aligned}
$$

Waktu siklus (c) yang dipilih adalah 100 detik.

(c). Waktu hijau $\left(g_{i}\right)$ untuk masing-masing pendekat:

$g_{i} \mathrm{~B}=(100-18) \times 0,41=33,62 \operatorname{detik} \approx 35$ detik

$g_{i} \mathrm{U}=(100-18) \times 0,21=17,22$ detik $\approx 18$ detik

$g_{i} \mathrm{~T}-\mathrm{RT}=(100-18) \times 0,14=11,48$ detik $\approx 12$ detik

Waktu hijau yang lebih pendek dari 10 detik harus dihindari, karena dapat mengakibatkan pelanggaran lampu merah yang berlebihan dan kesulitan bagi pejalan kaki untuk menyeberang jalan.

(d). Waktu siklus yang disesuaikan (c) :

$$
c=(35+18+12)+18=83 \operatorname{detik} \approx 100 \text { detik }
$$

(e). Kapasitas dan derajat kejenuhan :

Tabel 1. Nilai Hijau, Kapasitas, dan Derajat Kejenuhan Simpang Setelah Diberikan Alternatif Desain Waktu Hijau

\begin{tabular}{cccc}
\hline Kode Pendekat & $\begin{array}{c}\text { Waktu Hijau } \\
g \text { (detik) }\end{array}$ & $\begin{array}{c}\text { Kapasitas } C \\
(\text { smp/jam })\end{array}$ & $\begin{array}{c}\text { Derajat Kejenuhan } \\
D S\end{array}$ \\
\hline B & 35 & 934,88 & 0,84 \\
U & 18 & 294,71 & 0,82 \\
T - RT & 12 & 3012,01 & 0,24 \\
\hline
\end{tabular}

Terlihat jelas bahwa besarnya derajat kejenuhan pada pendekat barat, utara dan timur-RT besarnya masing-masing adalah sebesar $0,84,0,82,0,24$. Sedangkan syarat menurut MKJI 1997 besarnya derajat kejenuhan pada ruas simpang adalah sebesar 0,75.

(f). Perilaku lalulintas : 
Tabel 3. Panjang Antrian Setelah Diberikan Alternatif Desain Waktu Hijau

\begin{tabular}{cccccc}
\hline Kode Pendekat & $N Q_{l}$ & $N Q_{2}$ & Total $N Q$ & $N Q M A X$ & $\begin{array}{c}\text { Panjang Antrian } \\
(\mathrm{m})\end{array}$ \\
\hline $\mathrm{B}$ & 1,48 & 19,68 & 21,16 & 31 & 131,9 \\
$\mathrm{U}$ & 1,43 & 5,73 & 7,16 & 13,2 & 105,6 \\
$\mathrm{~T}-\mathrm{RT}$ & 0,9 & 18,16 & 19,06 & 28,5 & 67,86 \\
\hline
\end{tabular}

Setelah diberikan alternatif desain waktu hijau pada masing-masing pendekat, dari Tabel 3 di atas dapat diketahui bahwa terjadi penurunan panjang antrian yang cukup, khususnya pada pendekat Barat. Setelah diberikan alternatif ini dicapai hasil perhitungan untuk kendaraan henti rerata sebesar 0,22 stop/smp dan tundaan simpang rerata 13,38 detik. Sehingga dari tundaan simpang rerata tersebut dapat didefinisikan tingkat pelayanannya adalah B.

Dari hasil data di atas dapat disimpulkan bahwa dengan diberikan alternatif desain waktu hijau pada simpang tiga Jogja Phone Yogyakarta sudah mengalami peningkatan pelayanan yang baik, sehingga dapat melayani pengguna jalan dengan baik, dibandingkan dengan alternatif desain lainnya karena lebih ekonomis dan tidak membutuhkan biaya yang begitu besar. Hasil perbandingannya dapat dilihat pada Tabel 4 dan Tabel 5 di bawah.

Tabel 4. Perbandingan Nilai Hijau, Kapasitas, Derajat Kejenuhan Simpang, dan Panjang Antrian Setelah Diberikan Alternatif Desain Waktu Hijau

\begin{tabular}{ccccccccc}
\hline \multirow{2}{*}{$\begin{array}{c}\text { Kode } \\
\text { Pendekat }\end{array}$} & \multicolumn{2}{c}{$\begin{array}{c}\text { Waktu Hijau } g \\
\text { (detik) }\end{array}$} & \multicolumn{2}{c}{$\begin{array}{c}\text { Kapasitas } C \\
\text { (smp/jam) }\end{array}$} & \multicolumn{2}{c}{$\begin{array}{c}\text { Derajat } \\
\text { Kejenuhan } D S\end{array}$} & \multicolumn{2}{c}{$\begin{array}{c}\text { Panjang Antrian } \\
(\mathrm{m})\end{array}$} \\
\cline { 2 - 9 } & Sblm & Ssdh & Sblm & Ssdh & Sblm & Ssdh & Sblm & Ssdh \\
\hline B & 22 & 35 & 588 & 934,88 & 1,33 & 0,84 & 643,53 & 131,9 \\
U & 22 & 18 & 360 & 294,71 & 0,67 & 0,82 & 17,27 & 105,6 \\
T-RT & 18 & 12 & 1063,2 & 1204,8 & 0,11 & 0,24 & 23,81 & 27,14 \\
\hline
\end{tabular}

Setelah diberikan alternatif ini dicapai hasil perhitungan untuk kendaraan henti rerata dan tundaan simpang rerata. Sehingga dari tundaan simpang rerata tersebut dapat didefinisikan tingkat pelayanannya yang disajikan dalam Tabel 5.

Tabel 5. Perbandingan Kendaraan Henti Rerata, Tundaan Simpang Rerata dan Tingkat Pelayanan.

\begin{tabular}{cccc}
\hline Perbandingan & $\begin{array}{c}\text { Kendaraan Henti Rerata } \\
\text { (NSTOT) } \\
\text { (stop/smp) }\end{array}$ & $\begin{array}{c}\text { Tundaan Simpang } \\
\text { Rerata(D1) } \\
\text { (detik) }\end{array}$ & $\begin{array}{c}\text { Tingkat } \\
\text { Pelayanan }\end{array}$ \\
\hline Sebelum & 2,09 & 233,19 & F \\
Sesudah & 0,22 & 13,38 & B \\
\hline
\end{tabular}

Lama waktu untuk setiap ruas jalan pada persimpangan di lapangan setelah adanya alternatif desain waktu hijau ditunjukkan dengan diagram, yang dapat dilihat pada Tabel 6. 
Tabel 6. Lama Waktu untuk Setiap Ruas Jalan pada Persimpangan di Lapangan Setelah Adanya Alternatif Desain Waktu Hijau

\begin{tabular}{ccccc}
\hline Simpang & Hijau (Detik) & $\begin{array}{c}\text { Kuning } \\
(\text { Detik) }\end{array}$ & Merah (Detik) & Jumlah (Detik) \\
\hline Barat & 35 & 3 & 62 & 100 \\
Utara & 22 & 3 & 75 & 100 \\
Timur- RT & 18 & 3 & 79 & 100 \\
Timur-ST1 \& ST2 & 45 & 3 & 52 & 100 \\
\hline
\end{tabular}

\section{Pengaruh derajat kejenuhan terhadap angka henti stop}

Analisis Pengaruh derajat kejenuhan dan rasio hijau terhadap angka henti stop menggunakan SPSS 15 yaitu uji t. Uji ini digunakan untuk mengetahui apakah dalam model regresi variabel independen $\left(\mathrm{X}_{1}, \mathrm{X}_{2}, \ldots . . \mathrm{X}_{\mathrm{n}}\right)$ secara parsial berpengaruh signifikan terhadap variabel dependen (Y). Dari hasil analisis regresi output disajikan sebagai berikut:

Tabel 8. Pengaruh derajat kejenuhan terhadap angka henti stop Coefficients (a)

\begin{tabular}{|c|c|c|c|c|c|c|}
\hline \multirow[b]{2}{*}{ Model } & & \multicolumn{2}{|c|}{$\begin{array}{l}\text { Unstandardized } \\
\text { Coefficients }\end{array}$} & $\begin{array}{l}\text { Standardized } \\
\text { Coefficients }\end{array}$ & \multirow{2}{*}{$\mathrm{t}$} & \multirow{2}{*}{$\begin{array}{c}\text { Sig. } \\
\text { Std. Error }\end{array}$} \\
\hline & & $\mathrm{B}$ & Std. Error & Beta & & \\
\hline \multirow[t]{3}{*}{1} & (Constant) &,- 889 & 1,914 & &,- 464 & ,667 \\
\hline & derajat kejenuhan & 3,181 & 1,585 & ,713 & 2,007 & 115 \\
\hline & rasio hijau &, 253 & 5,355 &, 017 &, 047 &, 965 \\
\hline
\end{tabular}

a Dependent Variable: angka henti

Rumusan Hipotesis

Ho: tidak ada pengaruh signifikan antara derajat kejenuhan dengan Angka henti stop

Ha: ada pengaruh signifikan antara derajat kejenuhan dengan Angka henti stop

Menentukan tingkat signifikansi

Berdasarkan table diatas diperoleh $\mathrm{t}$ hitung sebesar 2,007. Tabel distribusi $\mathrm{t}$ dicari pada tingkat keyakinan 95\%, a = 5\%: $2=2,5 \%$ (uji 2 sisi) dengan derajat kebebasan (df) $n-$ $\mathrm{k}-1$ atau 7-2-1 = 4 (n adalah jumlah kasus dan $\mathrm{k}$ adalah jumlah variabel independen) dan dengan pengujian 2 sisi (signifikansi $=0,025$ ). Hasil pengujian diperoleh untuk t tabel sebesar 3,4954. Oleh karena nilai $-\mathrm{t}$ tabel $<\mathrm{t}$ hitung $<\mathrm{t}$ tabel $(-3,4954<2,007<3,4954)$ maka Ho diterima, hal ini berarti secara parsial tidak ada pengaruh signifikan antara derajat kejenuhan dengan angka henti stop.

\section{KESIMPULAN}

Tingkat pelayanan pada simpang tiga Jogja Phone Yogyakarta pada masa sekarang sangat rendah yaitu kategori $\mathrm{F}$ dengan tundaan 233,19 detik/smp. Hal ini disebabkan kapasitas jalan sudah tidak sesuai dengan arus lalulintasnya, terutama pada lengan Barat. Setelah dilakukan pengaturan kembali waktu siklus lalulintas, diperoleh tingkat pelayanan $\mathrm{B}$ dengan tundaan 13,38 detik/smp. Hasil pengaturan waktu hijau diperoleh untuk pendekat Barat, Utara dan Timur masing-masing sebesar 35 detik, 18 detik dan 12 detik. Hasil analisis menggunakan SPSS 15 diketahui bahwa tidak ada pengaruh secara signifikan antara derajat kejenuhan terhadap angka henti stop.

\section{DAFTAR PUSTAKA}

[1]. Oglesby, C. H., dan Hicks, R.G., 1982, Teknik Jalan Raya, Edisi keempat jilid satu, Erlangga, Jakarta. 
[2]. Hoobs, F. D., 1995, Perencanaan dan teknik lalulintas, Gadjah Mada University Press Yogyakarta.

[3]. Anonim, 1997, Manual Kapasitas Jalan Indonesia, Direktorat Jendral Bina Marga, Departemen Pekerjaan Umum.

[4]. Anonim, 1994, Highway Capacity Manual, Special Report 209, Third Edition, National Research Council, Washington DC 